Anat. Labor. of Prof. H. SETO, Tohoku University, Sendai.

\title{
Histology and Innervation of Lung in Bat.
}

\author{
蝙蝠肺の組 織学と神経分布。
}

Toru NUMATA 沼田透.

(Received November 24, 1955،)

\section{Introduction.}

Many researchers have published reports on the histological studies of the innervation of the lung, among whom SUNDER-PLASSMANN, MIZUKOSHI, MAGNENAT and SAITO may be mentioned as authors that have made recent contributions, and thanks to these studies, many notable achievements have resulted. In particular, the innervation of the lungs of human adults was brought to clear light owing to the laborious study by HAYASHI and the genetic study of human lungs was greatly furthered by the researches of MIZUKOSHI on the lungs of human embryos. Such efforts have resulted in a rapid advancement of our knowledges concerning the subject. The study by SAITO was conducted with canine lungs as objective from a comparative anatomomical point of view. This study is also full of extremely interesting observations.

My interest on the subject, as SAITO's, was raised from the comparative anatomical angle, and taking my materials from bats, the only mammals that have the habit of flying through the air, I tried to study the innervation of their lungs, in comparison with that of man and dog. A number of such materials were fixed in $10 \%$ neutral formol for a long time, cut into $40 \mu$ frozen sections and silverimpregnated with SETO's method. The large series of beautiful tissue preparations thus obtained I subjected to minute microscopic observations and arrived at the findings described below.

\section{Individual Findings.}

Before entering upon a detailed description of the innervation of bat lung, I will speak a word on its fine structure that shows a considerable difference from that in man or dog, because it is thought that the histology of the bat lung is not yet adequately made clear.

Since the lung of a bat is much smaller than that of man or dog, the large bronchial branches, after branching out from the bronchus, very soon give up their places to intermediate and small branches, which also shortly pass over into bronchioli. These bronchioli, however, take comparatively long courses before passing over into. alveolar ducts and 
ending in alveolar sacs (Fig. 1). What is particularly notable in the fine

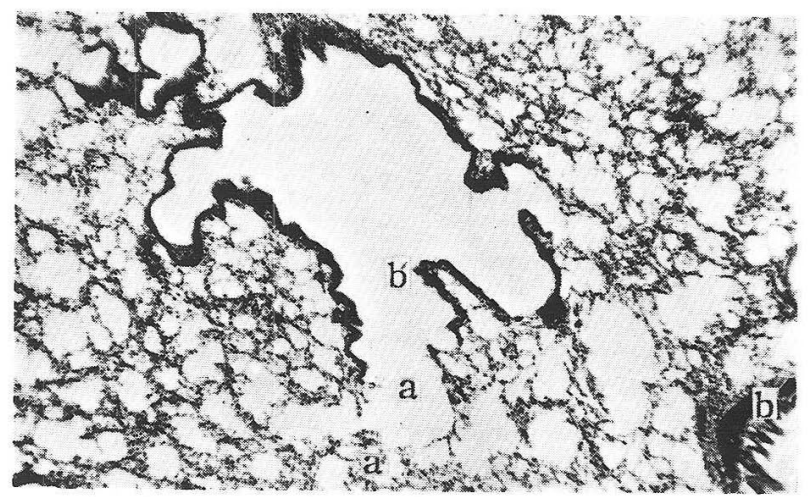

Fig. 1. Lung parenchyma of a bat. $b$ small bronchial branch; $b^{\prime}$ bronchiolus; $a$ alveolar duct; $a^{\prime}$ alveolar sac. SETO's impregnation. Photo $\times 30$.

structure of the bat lung is that the existence of cartilage pieces is limited to the thickest part of the branches close to the bronchus, such pieces being found nowhere in any other part of the bronchial branches. These cartilages are essentially of hyaline nature, but interestingly enough, they very often show inchoate ossification. In the part where the cartilages are found, the mucous membrane shows no fold formation, and only connective tissue is formed between the epithelium and the cartilages, but neither smooth muscle nor bronchial glands are found here. The epithelium consists only of $1-3$ rows of cylindrical ciliated cells and contains no goblet cells found in human or canine counterpart. The subepithelial basal membrane is very indistinct.

As the part of the bronchial branches without cartilages is surrounded by a well-developed smooth muscle layer, the mucous membrane in such a part shows conspicuous formation of longitudinal folds. The propria is very narrow, but the smooth muscle layer surrounding circularly the bronchial branches is rather thick. This is very different from the muscle layer of the media of arterial walls in that the latter is formed of a succession of eircular smooth muscle bundles gradually diminishing in thickness toward the periphery. The muscle bundles here ranged circularly in a row with small interspaces and connective tissue septa are formed between them.

Around the muscle layer we find an adventitia consisting of a connective tissue not so large in thickness, in which gatherings of lymphocytes and solitary lymph follicles are frequently observable (Fig. 7). Such lymphatic formations are quite as often found in the propria also (Fig. 9!. To my surprise, I found the bronchial glands as ill developed 
as the cartilages in bat lung, almost none of them being observed in any part of the bronchial branches.

The above detailed histology of the cartilageless large bronchial branches may be applied to the intermediate bronchial rami as well with little change, that is to say, the fine structure here shows no essential difference from the above, except that the general size, of course, is decreased and that the folds in the mucous membrane rather become somewhat taller (Fig. 2). Passing over into the small bronchial rami, we find the epithelium consisting in a single-rowed ciliated epithelium and the thickness of the smooth muscle layer diminished. The fold formation of the mucous membrane, however, is still clearly demonstrable.

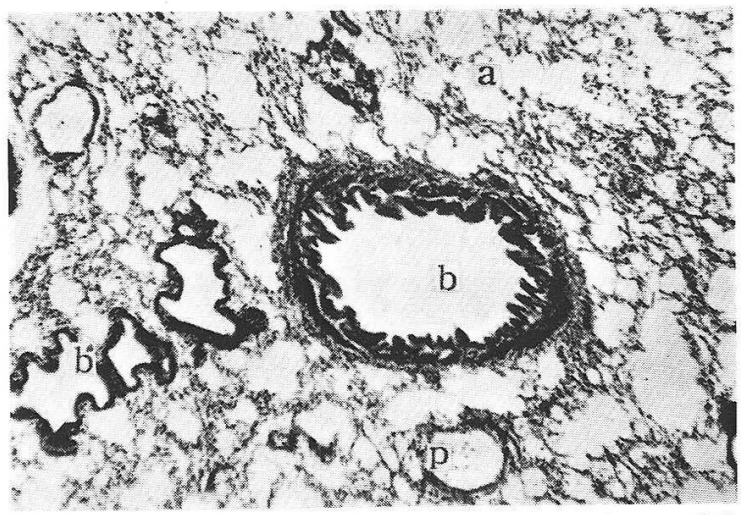

Fig. 2. Ditto. $b$ intermediate bronchial branch provided with longitudinal mucous folds; $b^{\prime}$ bronchiolus; $a$ alveolar duct; $p$ small a. pulmonalis. Same staining. Photo $\times 30$.

The bronchioli in bats do not admit clear-cut distinction into-terminales and respiratorii, as in man, because the epithelium in bat bronchioli is always single-rowed and ciliated as in the small bronchial branches, and moreover, we can find no alveoli appearing even in the parts that should correspond to the bronchioli respiratorii in man (Fig. 1). Upon passing over from the bronchioli into the alveolar ducts, the epithelium suddenly changes over from a ciliated epithelium into a alveolar epithelium. By the way, the epithelium in the bronrchioli is lined almost directly by a single row of smooth muscle fibres (Fig. 12).

The alveoli in bat, as well as in man and dog, are made of alveoli arranged in consecution, which finally pass over into alveolar sacs, also formed of sheer alveoli. An alveolus consists of flat cells partly with round or oval nuclei and partly whithout any nuclei (Figs. 16 and 17). Blood capillaries with elongated endothelial nuclei are found along the 
outer surface of such alveoli. The distinction between the interstitial septa and the interstitial connective tissue is very hard to make. The pleura visceralis is formed of a thin connective tissue with endothelial cells arranged in a single row on its surface (Fig. 18).

The arteria pulmonalis and the vena pulmonalis are very easily distinguishable, as their mediae are made of entirely different muscle fibres, as has been pointed out by several researchers. The media in the former, as in man and many other animals, is made of smooth muscle fibres, which show conspicuous thickening at many places in their layer. The media of the vena pulmonalis lining the extremely thin intima from the thickest part to the peripheral smallest part throughout wholly consists of heart muscle tissue. Its externa is of a very thin connective tissue. In short, this vein is essentially an extension of the atrium cordis and its media is consequently represented by an extension of the heart muscle tissue. Moreover, this media of the v. pulmonalis shows a much larger fluctuation in its thickness than that a. pulmonalis and its crosssection is extremely irregular, being devoid of any definite shape (Fig. 3), while a transverse section of the a. pulmonalis has the constant form

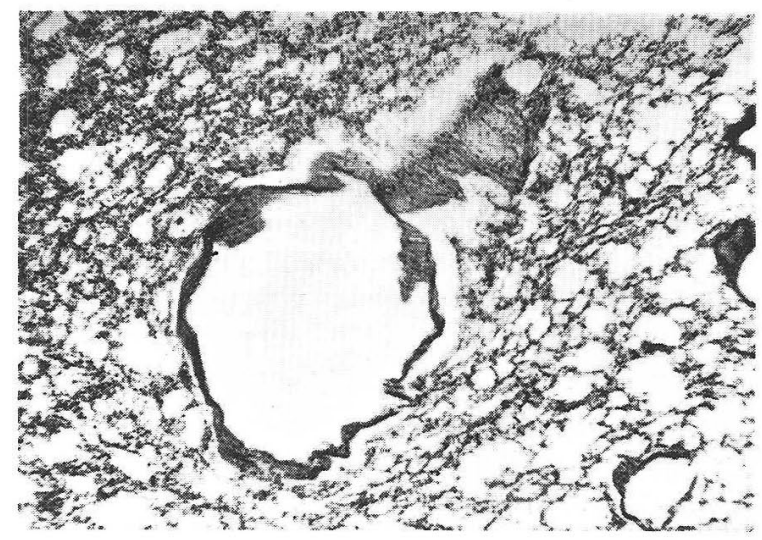

Fig. 3. V. pulmonalis in lung parenchyma of a bat. Heart muscle tissue in the media is clearly observable. Details in the text. Same staining. Photo $\times 30$.

of a circle. Thus, the two vessels can be readily distinguished by mere outward form, particularly, in the periphery. The vasa bronchialia running into the adventitia of the bronchial branches are merely very small blood vessels.

Among the histological findings of the lungs of bats, we must point out the following as the most noteworthy. Pieces of cartilage of hyaline nature, which very frequently show signs of ossification, are found only in a limited range of the large bronchial branches. Here, no formation 
of mucous folds is demonstrable. The bronchial branches contain neither cartilage nor bronchial glands in any other parts, where, however, owing to the marked development of the smooth muscle layer, the mucous membrane has conspicuous longitudinal folds fromed in it. The epithelium of the mucous membrane consists in a low ciliated epithelium containing no goblet cells. The bronchioli are lined by a single-rowed ciliated epitheilum and contain no alveoli. The epithelium is lined by thin smooth muscle fibres arranged in one row. The media of the vena pulmonaris consists of heart muscle fibres and is subject to violent fluctuation in its thickness, so that the vein shows a large lumen of very indefinite form.

As in man and other animals, plexus pulmonaris anterior and posterior consisting of sympathetic and parasympathetic (nervus vagus) elements are found running into the bat lung through the lung hilus and along the bronchial branches. These plexuses, however, are quantitatively much inferior to those in man and considerably poorer than those in dog. The nerve bundles forming the plexus run through or more frequently along the adventitia of the bronchial branches, but in some parts, they slightly penetrate also into the lung parenchyma around the bronchial branches, before passing into their periphery.

Nerve cells are seen frequently gathered on the courses of such bundles, but the number of nerve cells in such gatherings is very small, no such large ganglia containing 80-100 cells as found in dog lung being observed in bat. In bat, the largest ganglia consist only of 1520 cells, most of them comprising only $4-5$ nerve cells (Figs. 4 and 5). Some nerve cells are found in solitary existence at many places.

The nerve cells are naturally much smaller than those in man and dog, but their essential characteristic of multipolarity is not lost. Cells with conspicuous nerve processes, however, are found only very rarely, and most of the cells give the appearance of being apolar. The distinction of the cells into the DOGIEL's so-called Type $\mathrm{I}$ and Type II is almost entirely impossible (Figs. 4 and 5). Thus, the development of the sympathetic nerve cells here is much poorer than of those in man and dog, and at least on this score, a bat may be taken to be a lowlier animal than a dog.

The nerve bundles of the intrapulmonary nerve plexus are formed of very fine unmyelinated vegetative fibres and thick myelinated sensory fibres, but in many cases the latter predominate over the former in number, and sometimes only the latter come into the formation of the bundles. The large predominance of the number of sensory fibres over that of vegetative fibres seems to suggest that their origin is not limited to the $\mathrm{n}$. vagus only, but some cervical or thoracal nerves also contribute 


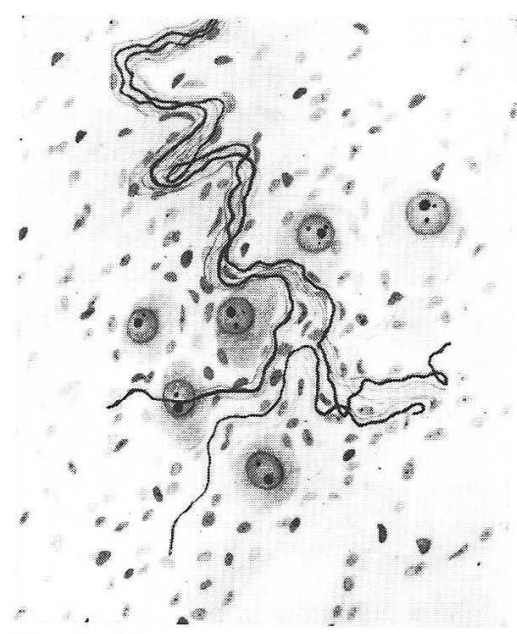

Fig. 4. Plexus peribronchialis accompanied by 6 nerve cells and formed along the adventitia of a large bronchial branch of a bat. Nerve bundles are composed of fine non-medullated vegetative and thick medullated sensory fibres. Nerve processes of nerve cells are developed very weak. Same

staining. $\times 600$, reduced to $2 / 3$.

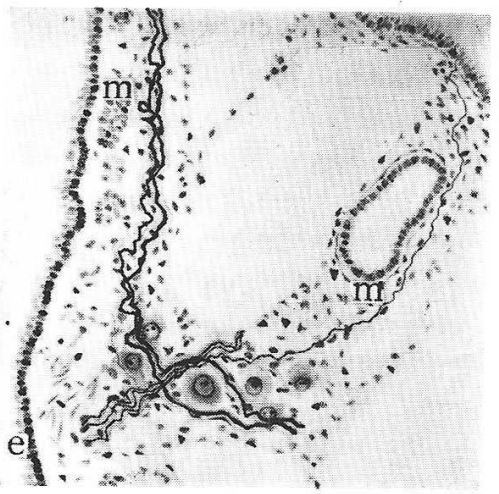

Fig. 5. Plexus peribronchialis found in the adventitia of an intermediate bronchial branch of a bat. Nerve bundles are composed of fine vegetative and thick sensory fibres and accompanied by a small ganglion containing 6 nerve cells whose nerve processes are developed very weak. $e$ low ciliated epithelium; $m$ circular smooth muscle layer; $m^{\prime}$ smooth muscle fibres around a bronchiolus. Same staining. $\times 400$, reduced to $1 / 2$.

to their formation. The termination of the vegetative fibres always consists in STÖHR's terminal reticulum here also, in agreement with the

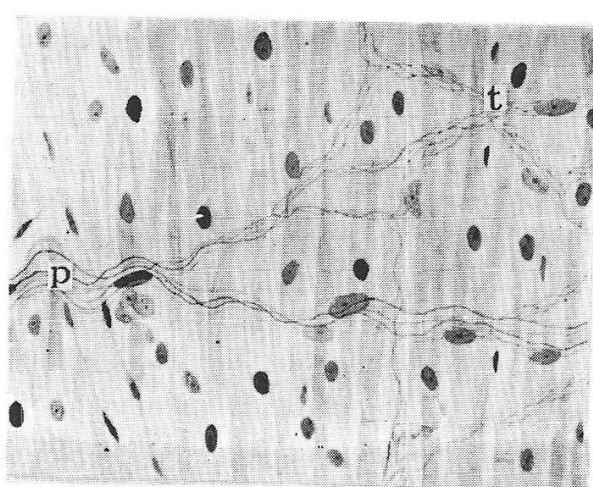

Fig. 6. Vegetative nerve fibres distrituted in the media composed of heart muscle tissue of $v$. pulmonalis in a bat lung. $p$ praeterminal fibres; $t$ terminal reticulum. Same staining. $\times 400$, reduced to $2 / 3$. results of many studies conducted in this laboratory, a id the formation of such net-works is especially good in the muscle fibres.

Another part of the vegetative fibres forms perivascular plexus around the flood vessels. In the externa of a. pulmonalis of bat, however, the quantity of vegetative fibres forming such plexus is very small. It is quite otherwise with the v. pulmonalis, where a rather large number of fine vegetative fibres are seen 
running in along the outside of the media of heart muscle fibres, and penetrating even into the media, finally to end in terminal reticula there (Fig. 6), as in human heart (SETO). The sensory terminations so prevalent in the human atrium cordis (SETO), however, could not be proved to exist in the v. pulmonalis of bat.

Looking through the reported results of the past studies on the terminations of the pulmonary sensory fibres, we find that SUNDERPLASSMANN has first discovered terminations Type I concerned with the blood pressure fall reflex in the muscle layer of the human intrapulmonary bronchial rami and HAYASHI succeeded in finding and describing similar terminations and intraepithelial branched terminations in the same. MAGNENAT is said to have found myelinated fibres diffused as far as the respiratory bronchioli and the alveolar ducts of human lungs. More recently, SAITO has found, in his study of the innervation of dog lung, terminations Type I for the blood pressure fall reflex and simple branched terminations in the muscle layer of the bronchial branches, unbranched and branched terminations in the tunica propria, intraepithelial fibres in the epithelium and simple sensory terminations formed subepithelially in the bronchioli. Such terminations in canine lungs were considerably inferior in complexity to those in human lungs.

The findings of the author on the terminations of the many sensory fibres running in the bat lung may be summarized as follows. These sensory fibres mostly run through the connective tissue of the adventitia and the muscle layer into the propria and sometimes further into the epithelium, to form their terminations there. In some rare cases, however, simple branched terminations are formed on the course in the adventitia, and also in a small number in the muscle layer. The terminations in the muscle layer are limited in existence to the large or intermediate bronchial branches and are not found in the small bronchial rami.

The above mentioned terminations are either of unbranched or branched type. Some of the branched terminations are formed by rather thin fibres (Fig. 8); but some of them originate in very thick fibres. In a termination of the latter kind, considering the fact that the terminal fibres are of comparatively large number and that these show rather conspicuous change in size during their courses, we find them closely resembling the sensory terminations concerned with the blood pressure fall reflex, especially, those found in dog lung (SAITO). As exemplified in Fig. 7, a very stout sensory fibre branches out into a number of terminal rami, which run characteristie winding courses showing very perceptible change in size, and here and there in this terminal area, 


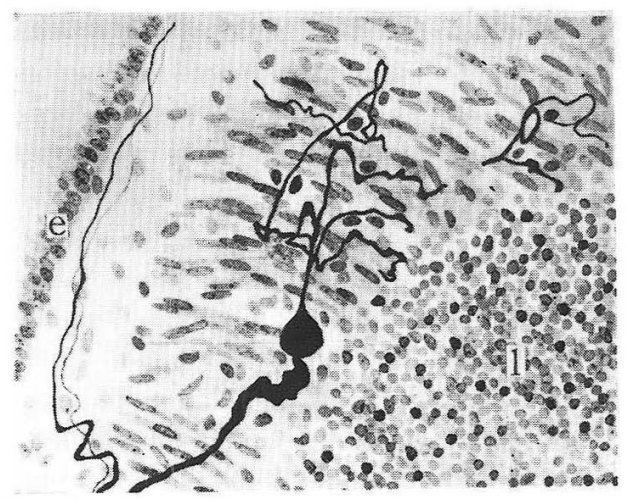

Fig. 7. A termination Type I concerned with blood pressure fall reflex found in a muscle layer of a large bronchial branch of a bat. Details in the text. $l$ lymphocyte gathering in the adventitia; $e$ low ciliated epithelium. Same staining. $\times 400$, reduced to $2 / 3$.

we find existence of round or oval special nuclei. Thus, though no marked neurofibrillar expansions are apparent, as in those in human lungs, (such an apparent absence of strong fibrillar expansion may be common to all small animals) we may assume that these belong to the terminations Type I concerned with the blood pressure fall roflox. The terminations of this type in bat lung are thus much smaller than those in man and somewhat poorer than those in dog.

Most of the sensory fibres in the bronchial walls run into the narrow propria. Such sensory fibres in the bronchioli without folds in their mucous membrane are limited in number and form only vory simple terminations, but those in the bronchial branches with conspicuous mucous folds are numerous and end in considerably complex terminations. For, in the latter parts, a rather large quantity of connective tissue exists in the folds, facilitating the distribution of sensory fibres therein.

The sensory terminations in the propria are either of unbranched or branched type, and their quantity is much larger in bat than in dog. In the bronchial branches containing well-developed muscle layer and mucous folds, unbranched terminations are very few, branched terminations occupying the largest majority of the sensory endings here. In the bronchioli where muscle layer is ill-developed and nearly no fold formation is observed, however, the largest part of the endings are in the form of unbranched terminations.

The branched terminations formed in the propria of the bronchial branches may be subdivided into those of simple and complex types, the 
latter being found in a number in the large and the intermediate branches and the former in the small branches. In dog, complex typed branched terminations have been found nearly absent in the propria of bronchial branches, and this prevalence of comptlex branched terminations in the same part of bats is an interesting finding that mas be taken to indicate a superiority, at least in respect of bronchial sensory innervation, of bats over dogs. Branched terminations originating in extraordinarily thick sensory stem fibres are not rare also.

Fig. 8 shows a complex branched termination formed in the propria of a large bronchial branch. In this termination, the stem fibre is rather thin and the numerous rami sent out by it lose gradually in size to end sharply. Figs, 9, 10 and 11 show a little complex branched termination

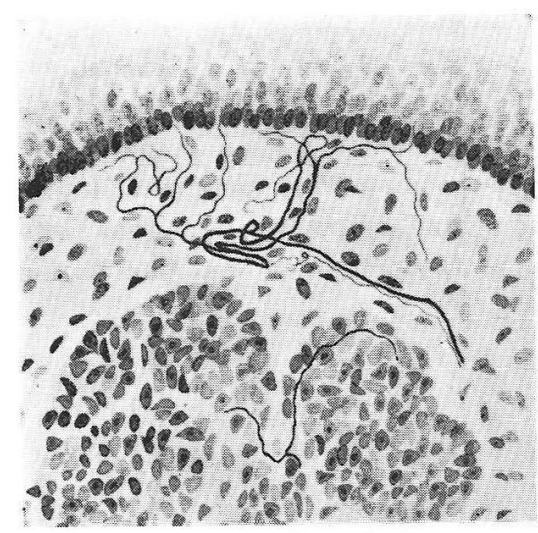

Fig. 8. A complex branched termination found subepithelially and a simple branched termination in the muscle layer. Sagittal section of a large bronchial branch of a bat. Epithelium is cut somewhat obliquely. Same staining. $\times 400$, reduced to $4 / 5$. originated in thick sensory fibre respectively, whose many terminal branches diminish in size gradually and end sharply. In

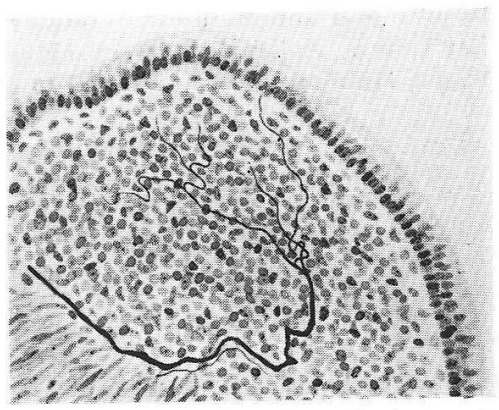

Fig. 9. A complex branched termination formed in a lymphocyte gathering in the propria of an intermediate bronchial branch of a bat. Same staining. $\times 400$, reduced to $2 / 3$.

Fig. 9, you see a termination formed in a gathering of lymphocytes in the propria. One terminal branch each is seen running into the epithelium to form an intraepithelial fibre in Figs. 10 and 11.

An unbranched and a simple branched terminations found subepithelially in the bronchioli are respectively illustrated in Figs. 12 and 13. As shown here, the sensory fibres run very long and more or less winding courses along the walls of the bronchioli, and diminishing in size taper off in sharp points. Such fibres may very often end intraepithelially. Thus, numerous sensory terminations may be found in the bronchioli of bat, but they are always extremely simple in structure. 


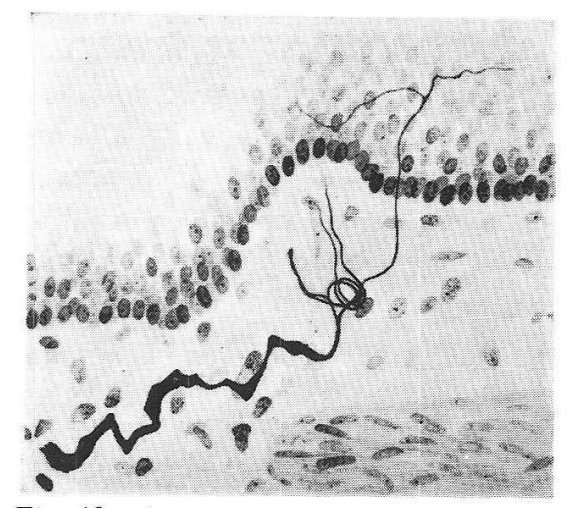

Fig. 10. A comparatively complex branched termination originated in a very thick sensory fibre and formed in the propria of an intermediate bronchial branch of a bat. One of the terminal branches penetrates into the epithelium, to pass over into bifurcated intraepithelial fibres. Epithelium is cut obliquely. Same staining. $\times 600$, reduced to $4 / 5$.
As stated above, intraepithelial fibres may be found in the bronchial walls of bat in a rather large quantity, and these form in many cases considerably complex branched intraepithelial terminations in the bronchial walls other than those of the bronchioli. In Figs. 10 and 11, a part of the terminal fibros of the branched terminations formed in the propria end in simple intraepithelial fibres, but in Figs. 14 and 15 we see complex branched intraepithelial fibros illustrated. Here, a single thick sensory fibre each, after losing its myelin sheath, runs into the epithelium and then begins

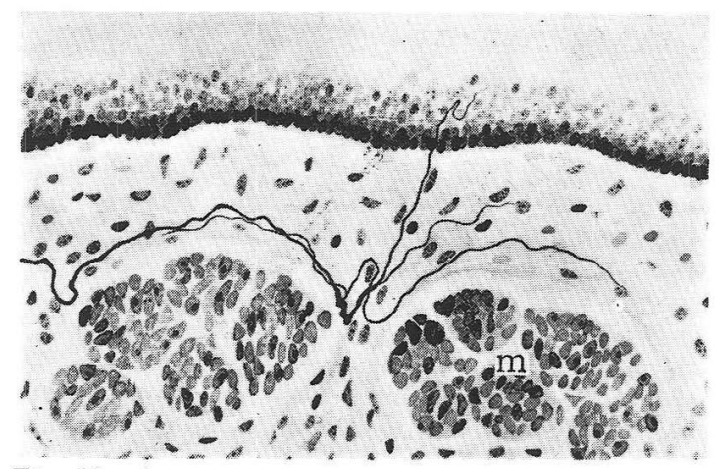

Fig. 11. A comparatively complex branched termination formed in the propria of a large bronchial branch of a bat. One of the terminal branches enters into the epithelium, to become an intraepithelial fibre. $m$ transverse section of a circular muscle layer. Same staining. $\times 400$, reduced to $2 / 3$.

to ramify into many terminal branches, which, running peculiar winding courses inter- and intra-cellularly, lose gradually in size to end in sharp points. Most of the terminal branches shown in Fig. 15 once penetrate into the epithelium, come out of it again, and then reenters it to end therein. Such complex branched iafraepithelial fibres were found only 


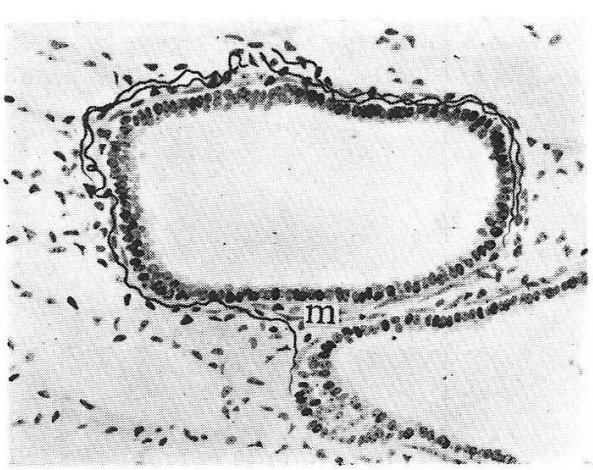

Fig. 12. 4 Unbranched terminations distributed subepithelially around a bronchiolus of a bat. $m$ thin smooth muscle layer. Details in the text. Same staining. $\times 400$, reduced to $2 / 3$.

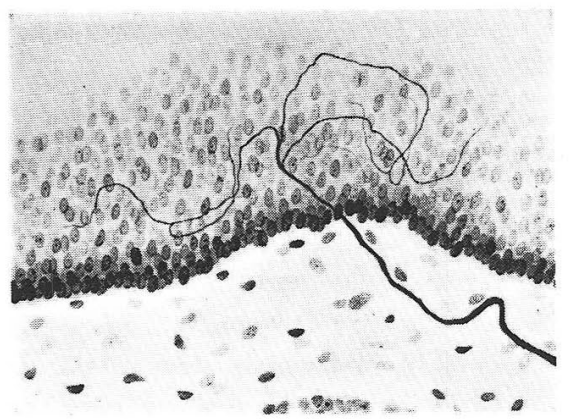

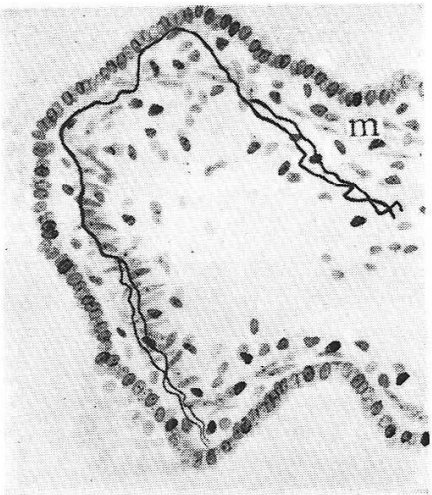

Fig. 13. A bifurcated termination formed subepithelially around a bronchiolus of a bat. $m$ thin smooth muscle layer. Details in the text. Same staining. $\times 400$, reduced to $2 / 3$.

Fig. 14. A complex branched intraepithelial termination originated in a very thick sensory fibre found in a large bronchial branch of a bat. Epithelium is cut obliquely. Same staining. $\times 600$, reduced to $2 / 3$.

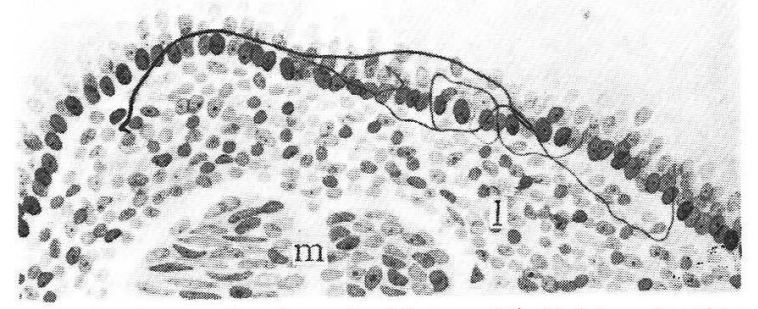

Fig. 15. A complex branched intraepithelial termination found in a large bronchial branch of a bat. Details in the text. $l$ lymphocyte gathering in the propria; $m$ transverse section of a smooth muscle bundle. Same staining. $\times 400$, reduced to $4 / 5$. 
very rarely in dog lung (SAITO).

Fig. 16 shows an unbranched intraepithelial fibre ending sharply after a very long winding course, found in the epithelium of a bronchiolus of a bat cut somewhat in an oblique plane. The intraepithelial fibres in bat bronchioli end always in such unbranched terminations.

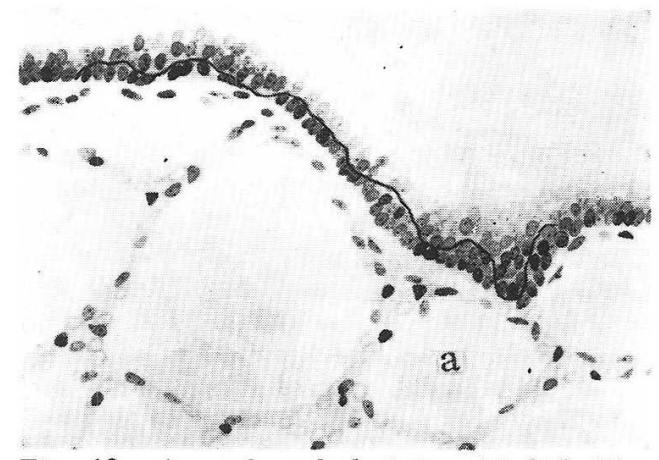

Fig. 16. An unbranched intraepithelial fibre found in a bronchiolus of a bat. a alvcolus. Details in the text. Same staining. $\times 400$, reduced to $2 / 3$.

What has been of particular interest to me among the sensory terminations in the lungs of bats were the sharply ending unbranched terminations found, though, maybe, in a small number only, in the interstitial connective tissue of the lung parenchyma and the unbranched terminations found in the pleura visceralis rather frequently. In particular, since no one has in the past succeeded in blamelessly demonstrating the existence of sensory terminations in the pleura, I feel justified in

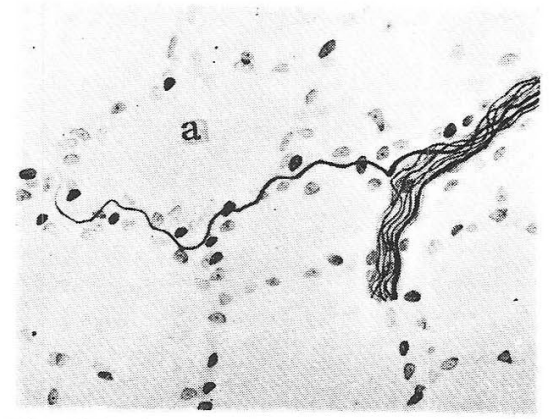

Fig. 17. An unbranched sensory termination found in the lung parenchyma of a bat. $a$ alveolus. Details in the text. Same staining. $\times 400$, reduced to $4 / 5$. claiming high significance for my discovery.

Fig. 17 shows an unbranched termination found in the parenchyma of a bat lung. The figure shows a nerve bundlet containing two thick sensory fibres running through the parenchyma from which one of the fibres parts from the bundle to run peripheralwards through the interstitial connective tissue and to end sharyly without branching out. In Fig. 18 is shown an unbranched sensory termina- 


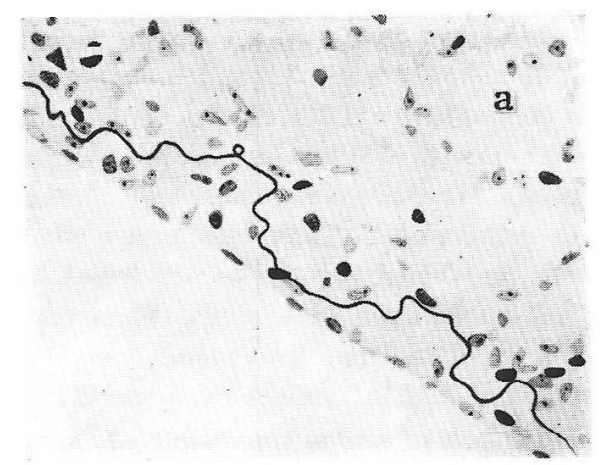

Fig. 18. An unbranched sensory termination found in the pleura visceralis of a bat. $a$ alveolus. Details in the text. Same staining. $\times 400$, reduced to $2 / 3$.

tion found in the weakly formed connective tissue in the pleura visceralis. As is exemplified here, the sensory fibres found in the bat pleura are usually of a comparatively thick size and, after losing their myelin sheaths, run very typical long winding courses to end in sharp points without ramifying.

As described in the preceding, I have succeeded in proving the existence of simplest unbranched terminations in the pleura visceralis of bats - animals of a rather low order - and that in a rather large quantity. This discovery seems to lead us to believe in the existence of the hitherto unknown sensory terminations in human visceral pleura, a suggestion of rather a deepest consequence.

\section{Summary.}

The bronchial branches of bats are very short, but the bronchioli are rather long and pass over into alveolar ducts and sacs. Pieces of cartilage are found only at the incipient part of the bronchial branches, and these very often show signs of ossification. The mucous membrane in such a cartilaged part do not show any fold formation.

The bronchial branches lose rather rapidly in size, but their fine structure undergo little essential change throughout, even down to the smallest branches. They are covered by a $1-3$ rowed ciliated epithlium containing no goblet cells and a row of well-developed circular muscle bundles surrounds the thin propria, so that the mucous membrane shows a conspicuous formation of longitudinal folds. This muscle layer is lined by an adventitia and frequently contains lymphocytic gatherings, which, besides, are also often found in the propria. Bronchial glands are found nowhere in the bronchial branches. 
Since the bronchioli are devoid of alveoli, it is impossible to make distinction between bronchioli terminales and bronchioli respiratorii. The epithelium here is a single-row ciliated one, surrounded by a row of very thinly arranged smooth muscle fibres, and no folds are formed in the mucous membrane. The alveolar ducts and sacs are nothing but alveoli arranged in consecution. These are composed of nucleated and unnucleated flat cells and blood capillaries are found lining the outside of them. The distinction between interlobular septa and interstitial connective tissue is very hard in bats. The pleura visceralis consists of an endothelial cell layer and a thin connective tissue layer.

The v. pulmonalis has a media consisting of heart muscle tissue showing great fluctuation of thickness and reaching down to the periphery. Accordingly, the vein shows extremely mutable cross-sections.

Most of the nerve bundles forming the peribronchial plexus of bat run along the outside of the adventitia toward the periphery. Frequent gatherings of nerve cells are seen along these bundles, but even the largest of such ganglia do not comprise more than 20 cells. The nerve cells do not lose their essential characteristic of multipolarity, but their nerve processes are extremely ill-developed, so that many of the cells present the appearance of being apolar. Thus, the development of sympathetic nerve cells is much inferior to that in dog (SAITO).

The nerve bundles of the peribronchial plexus are formed of unmyelinated vegetative fibres and medullated sensory fibres, but in bat, it is noteworthy that the latter are markedly in large number, unlike the case in man or dog. It is needless to say that the vegetative fibres here also end always in STÖHR's terminal reticula. Vegetative fibres are also found running along the outside of the v. pulmonalis. These run into the heart muscle tissue of its media, as in the heart, to form conspicuous terminal reticula there.

The sensory fibres found in the plexus penetrate from the adventitia through the muscle layer into the propria, and sometimes further into the epithelium, to form their terminations. A small number of terminations are also formed en route in the muscular layer too. Beside unbrarched and simple branched terminations, we find not rarely sensory terminations Type I concerned with blood pressure fall reflex in the muscle layer.

The number of sensory fibres running into the propria is small in the bronchioli and their terminal mode is limited to the simplest unbranched endings, but in the bronchial branches, especially, in the large and the intermediate branches, the number is larger and complex branched terminations are also found here and there beside the unbranched and the simple branched terminations. In such a complex termination, 
the terminal branches gradually lose in size and usually end in sharp points in the propria, but some of the branches frequently end in intraepithelial fibres.

A large number of intraepithelial fibres are found in the bronchial walls and many of them form rather complex branched terminations. In such a complex intraepithelial termination, a demyelinated sensory fibre runs into the epithelium before giving out many terminal branches, which take typical undulatory inter- and intra-cellular courses to end finally in sharp points. Intraepithelial fibres are proved also existing in the bronchioli, but here they nearly always terminate unbranched.

Unbranched terminations ending sharply are also found, in a small number indeed, in the parenchyma of the bat lung. That well-formed unbranched sensory terminations were found here and there in the pleura visceralis of bat seems to suggest that sensory terminations may be found in human pleura too - a finding full of deep interest.

In comparing the innervation of bat lung with that of canine lung, we find that in the development of symphthetic nerve cells in the lung, bats stand below dogs, but the development of the sensory fibres and their terminations the lung is much more powerful in bats than in dogs, and on this score, the Chiroptera may be called higher animals than the Canes.

\section{內 容 自 抄。}

螎蝠の気管支枝は短小であるが，細気管支は比較的長い，気管支枝は 1 - 2 列性の氈毛上皮で蔽われ，其固有膜は薄く周囲には発達良好な輪走平 滑筋束が 1 列飞配列し，軟骨片と気管支腺とは殆んど証明されず，粘膜は 著明な縦走蚫璧形成を示す。筋膜は外膜で包囲される，淋巴球集合は特に 固有膜内に形成される。細気管支は肺胞を所有せず，1列性の高毛毛上皮と 略ぼ之《外接する 1 列性平滑筋層とから成り，ここでは剔壁形成は見られ ない，肺胞管と肺胞囊とは肺胞の連続で表わされ，肺胞壁は有核性及び無 核性扁平上皮細胞と之に外接する血液毛細管飞富む間質結合織から構成さ れる，内臟胸膜は上皮細胞層と薄い結合織層とから成る，肺静脈は末梢飞 至るまで其中膜は極めて不規則の厚さの心筋線維層で表わされる。

蝙蝠気管支枝周囲性神経叢内飞も所々飞神経節の存在を見るが，其発達 は人や犬に於けるよりは遙か飞劣勢で，大きな神経節でも20ケ以上の神経 細胞の存在は見られない。且つ細胞は甚だ屢々無極性を示す。神経束は無 髄性の植物線維と有䯣性の知覚線維とから成るが，後者が目立って多量を 占める事は興味深い，植物線維の終末は蝙蝠肺内でも Stöhr 氏終網で表わ される. 肺静脈の心筋層内とは心蔵心筋内に於けると同様甚だ良好な発達 
の終網の形成が認められる.

神経叢内の知覚線維は外膜から筋層を通って固有膜内飞, 更飞上皮内飞 も進んで終末を形成するが，尚招其途上筋層内にも多少の終末形成を示す。 即ち筋層内には非分岐性及び単純性分岐性終末の外，甚だ太い線維江来 する血圧下降反射飞関する知覚終末第 $I$ 型も稀ならず発見される。

固有膜内に入る知覚線維は細気管支では其量も少なく, 且つ終末形成も 甚だ単純で，專ら非分岐性終末で表わされるが，気管支枝特に大型や中型 のものでは其量も多く，非分岐性及び単純性分岐性終末の外飞複雑性分岐 性終末も各所飞発見される。尚招之等終末の終末枝の 1 部は屡々上皮内線 維と移行する.

上皮内線維も螎蝠気管支枝壁飞忨多量飞見られ且つ複雑な分岐性終末で 表わされる事も屢々である，即ち髄鞘を失った知覚線維が上皮内に来て多 数の分岐に分れ，上皮細胞間及び細胞体内を通貫し夫々尖鋭状飞終る．尚 扔細気管支飞も上皮内線維が証明されるが。 之は概ね非分岐性終末で表わ される。

蝙蝠肺実質内飞も少量の非分岐性終末が発見される，又内臟胸膜内飞も 著明な非分岐性終末が所々飞発見された。之は人内臓胸膜の中飞も知覚終 末の存在するであろう事を示唆するものである.

蝠蝙肺の神経分布を犬の夫飞比較すると植物神経特飞神経細胞の発達は 犬と於けるよりも劣勢であるが，知覚線維及び其終末の発達は犬の場合よ りも遙かと強力であり，甚だ興味深いものがある。

\section{References.}

Hayashi : J. orient. Med. 27 (1937). - Hermann: Virchows Arch. 322 (1952). - Kölliker: Handbuch der Gewebelehre des Menschen. Bd. 3. Leipzig, W. Engelmann, 1902. - Larsell : J. comp. Neur. 33 (1921). - Larsell a. Dow : Amer. J. Anat. 52 (1933). - Magnenat : Acta anat. 13 (1951), cited in Excerpta med. 6 (1952). - Reiser: Z. Zellforsch. 15 (1932); Arch. Augenhk. 109 (1935); Acta neuroveget. 4 (1952). - Sato: A rch. hist. jap. 8 (1955). Saito : Arch. hist. jap. 9 (1955). - Seto : Arb. anat. Inst. Sendai. 19 (1936). Seto a. Fukuya ma : J. orient. Med. 25 (1936). - Stöhr : Mikroskopische Anatomie des vegetativen Nervensystems. Berlin, J. Springer, 1928. - Z. Zellforsch. 16 (1932), 21 (1934). - Acta neuroveget. 10 (1954). - SunderPlassmann: Dtsch. Z. Chir. 240 (1933). 